\title{
PENGEMBANGAN KEUANGAN MIKRO UNTUK PENGENTASAN KEMISKINAN
}

\begin{abstract}
Abstrak
Tulisan ini bertujuan untuk membedah fenomena kemiskinan dan keterkaitannya dengan peran dari Lembaga Keuangan Mikro (LKM). Pemberdayaan masyarakat miskin melalui usaha mikro adalah bentuk dari pengentasan dari kemiskinan. Upaya ini harus ditopang dengan diberikannya akses dan sistem kredit yang lebih luas kepada usaha mikro. LKM merupakan alternatif pemberian kredit yang mudah dalam pelayanan karena syarat-syaratnya ringan dan terjangkau oleh UKM. Indonesia memiliki keragaman dalam model

LKM dan telah memiliki banyak contoh keberhasilannya dalam pengembangan UKM. Namun fenomena ini kurang diperhatikan oleh pemerintah.

Pemerintah seharusnya menanggapi dengan serius dengan membuat Kebijakan yang mengatur LKM agar menjadi lebih kuat. Kebijakan perekonomian juga harus mendukung sektor industri rumah tangga/kecil (UKM) agar lebih berkembang. Bukti bahwa UKM mampu menggerakkan ekonomi rakyat miskin harus ditindaklanjuti dengan kebijakan yang mempermudah berkembangnya UKM.
\end{abstract}

Oleh

Dwi Harsono

FISE UNY

Kata Kunci: keuangan mikro, kemiskinan

\section{Pendahuluan}

Perguliran era reformasi ternyata belum memberikan hasil positif pada kehidupan berbangsa di Indonesia. Fenomena kemiskinan saat ini kembali menghantui pembangunan di Indonesia. Pada tahun 1970, sekitar $68 \%$ penduduk Indonesia dikategorikan miskin. Tahun 1996 persentase penduduk miskin menjadi $11 \%$. Menu-rut BPS (SMERU, 2002), pada bulan Agustus 1999 jumlah orang miskin menjadi 47,9 juta orang $(23,4 \%$ dari total penduduk). Sedangkan data terbaru Biro Pusat Statistik menyebutkan angka kemiskinan di Indonesia per November 2006 menunjukkan 39,05 juta 
Jiwa $(17,76 \%)$ berada di bawah garis komiskinan (BPS, 2006). Menurut Bank Dunia, angka kemiskinan di Indonesia mencapai 109 juta jiwa $(49,5 \%)$ apabila dihitung berdasarkan konsumsi per hari US\$ 2 (Suruji, 2006). Kedua laporan di atas menunjukkan hasil yang berbeda karena monggunakan parameter kemiskinan yang berbeda. Namun yang menjadi fokus utama bukanlah mempertentangkan perbedaan parameter tapi adalah semakin meningkatnya jumlah masyarakat miskin.

\section{Komiskinan}

Definisi klasik kemiskinan adalah ketidakmampuan seseorang dalam memenuhi kebutuhan konsumsi dasar dan meningkatkan kualitas hidupnya (SMERU, 2002: 1). Alasan mendasar dalam definisi tersebut adalah aspek fisik/material sehingga sering disebut sebagai kemiskinan matorial. Sedangkan kondisi saat ini, kemiskinan tidak hanya dihubungkan dengan aspek fisik/material saja tetapi juga aspek yang lebih luas seperti sosial dan moral, yakni kemiskinan sebagai ketidakberdayaan sekelompok masyarakat di bawah suatu sistem pemerintahan yang menyebabkan mereka berada pada posisi yang sangat lemah dan tereksploitasi. Definisi terakhir kemudian lebih dikenal sebagai kemiskinan struktural.

Kemiskinan diukur sebagai tingkat konsumsi per kapita di bawah suatu standar tertentu yang kemudian disebut garis kemiskinan. Mereka yang berada di bawah garis kemiskinan tersebut dikategorikan sebagai miskin. Garis kemiskinan dihitung dengan cara menjumlahkan: biaya untuk memperoleh "sekeranjang" makanan dengan kandungan 2.100 kalori per kapita per hari; dan biaya untuk memperoleh "sekeranjang" bahan bukan makanan yang diang-gap "dasar", seperti pakaian, perumahan, kesehatan, transportasi dan pendidikan (SMERU,2002: 2).

Peningkatan faktor-faktor penentu kemiskinan mer.ggulirkan lagi perkembangan definisi kemiskinan dengan juga melibatkan dimensidimensi tertentu. Menurut SMERU (2002), kemiskinan berwajah majemuk sehingga untuk memahaminya harus memperhatikan dimensi-dimensi kemiskinan, yaitu: 1) kerentanan, 2) ketidakberdayaan, dan 3) ketidakmampuan untuk menyampaikan aspirasi (voicelessness) (SMERU, 2002: 2).

Penyebab kemiskinan sangat banyak sehingga tidak mudah untuk disebutkan. Karakteristik kemiskinan di tiap daerah memiliki perbedaan. Dengan dimensi-dimensi kemiskinan, penyebab kemiskinan akan lebih mudah untuk diketahui dan dipahami secara utuh. Menurut SMERU, penyebab kemiskinan adalah: 1) Keterbatasan pandapatan, modal dan sarana untuk memenuhi kebutuhan dasar, 2) Keren- 
tanan dan ketidakmampuan menghadapi goncangan-goncangan, dan 3) Tidak adanya suara yang mewakili dan terpuruk dalam ketidakberdayaan di dalam institusi negara dan masyarakat (SMERU, 2002: 5).

\section{Penanggulangan Kemiskinan}

Menurut SMERU (2002), ada empat kebijakan dan program yang bisa dilakukan untuk penanggulangan kemiskinan (SMERU, 2002: 13). Empat kebijakan tersebut adalah:

1. Kebijakan dan Program untuk Membuka Peluang atau Kesempatan Bagi Orang Miskin

Kebijakan ini diarahkan pada pembukaan peluang yang seluas-luasnya kepada masyarakat miskin untuk ikut berpartisipasi dalam pembangunan ekonomi. Lemahnya kemampuan ekonomi masyarakat miskin bukan berarti menutup peluang untuk berpartisipasi dalam pembangunan. Justru aktivitas ekonomi yang yang pertama kali bangkit dari keterpurukan akibat krisis adalah sektor informal yang dijalankan masyarakat miskin. Contoh programnya antara lain adalah: penyediaan sarana kesehatan bagi masyarakat miskin, sarana dan prasarana pendidikan, pemberdayaan masyarakat, pembentukan modal, dan lainlain.

2. Kebijakan dan Program untuk Memberdayakan Kelompok Miskin

Pemberdayaan dilaksanakan dengan pembukaan akses bagi masyarakat miskin untuk terlibat tidak hanya pada bidang ekonomi. Kemiskinan memiliki aspek yang sangat luas dan tidak hanya ekonomi sehingga pe-nanggulangannya harus bersifat mul-tidimensi. Politik, sosial, hukum dan kelembagaan adalah bidangbidang yang bersentuhan dan menentukan kehidupan masyarakat miskin se-hingga aksesibilitas masyarakat ter-hadap lembagalembaga tersebut dapat mendorong masyarakat un-tuk memberdayakan diri. Contoh programnya antara lain: penguatan pengelolaan kelompok atau crgani-sasi sosial, keterlibatan kelompok miskin dalam proses pendidikan de-mokrasi, dan lainlain.

3. Kebijakan dan Program yang Melindungi Kelompok Miskin

Masyarakat miskin sangat rentan terhadap terjadi goncangan internal maupun eksternal. Kematian, sakit, bencana alam atau konflik sosial bisa berakibat pada semakin terpuruknya masyarakat dalam kemiskinan. Hal ini disebabkan oleh ketiadaan jaminan atau ketahanan masyarakat miskin terhadap krisis akibat goncangan yang terjadi. Kebijakan ini diarahkan untuk mengurangi penyebab terjadinya goncangan, memperkuat masyarakat miskin sehingga tahan dalam menghadapi goncangan, dan penciptaan jaminan sosial dalam masyarakat.

4. Kebijakan dan Program untuk Memutus Pewarisan ŕemiskinarı 
Antar Generasi: Hak Anak dan Peranan Perempuan

Perempuan dan anak-anak adalah pihak yang paling lemah dalam keluarga miskin. Peran domes-tik menyebabkan kurangnya akses dan keterlibatan terhadap kondisi di luar lingkungan rumahnya. Pemberdayaan dan keterlibatan pada kegiatan di luar wilayah domestik akan menghilangkan diskriminasi terhadap perempuan dan anak sehingga tidak semakin terpuruk dalam lingkaran kemiskinan. Contoh programnya aniara lain: pemberian bantuan sarana pendidikan untuk sekolah di daerah miskin dan beasiswa kepada anak-anak miskin, pemberian makanan tambahan, pemberdayaan perempuan melalui kegiatan produktif, dan lainlain (SMERU, 2002: 13-17).

\section{Usaha Kecil/Mikro}

Penanggulangan kemiskinan melalui usaha kecil/mikro menjadi bagian dari kebijakan yang bertujuan untuk membuka peluang dan kesempatan bagi masyarakat miskin untuk secara luas berpartisipasi dalam pembangunan ekonomi. Usaha mikro menurut lembaga-lembaga internasional adalah usaha non pertanian dengan jumlah pekerja maksimal 10 orang, menggunakan teknologi sederhana atau tradisional, memiliki keterbatasan akses terhadap kredit, mempunyai kemampuan managerial rendah dan cenderung beroperasi di sektor informal (SMERU Online, 2006). Sedang- kan menurut Bank Indonesia, usaha mikro adalah usaha produktif milik keluarga atau perorangan Warga Ne-gara Indonesia, secara individu atau tergabung dalam koperasi dan me-miliki hasil penjualan secara individu paling banyak Rp 100.000.000,00 (seratus juta Rupiah) per tahun (Bank Indonesia, 2005). Definisi usaha mikro yang dikemukakan oleh Bank Indonesia mencerminkan omzet maksimal dari sebuah usaha mikro. Definisi tersebut juga bisa berarti bahwa usaha yang memiliki hasil penjualan mencapai Rp 500.000,00 (lima ratus ribu rupiah) pun termasuk usaha mikro.

Usaha kecil/mikro yang berkembang dalam masyarakat beromzet kecil sehingga dikategorikan sebagai sektor informal. Meskipun informal, sektor ini mampu menggerakkan perekonomian dan menjadi sektor yang pertama kali bangkit akibat krisis (Wijono, 2005: 86). Kondisi ini masuk akal karena sektor inilah yang menjadi tulang punggung perekonomian rakyat (SME$\mathrm{RU}, 2002$ : 4). Kontribusi UKM terhadap produk domestik bruto ratarata mencapai 56,04 persen dan tenaga kerja yang diserap oleh UKM tahun 2004 mencapai 70,92 juta orang (BPS, 2005).

Keberhasilan sektor informal yang dimotori oleh usaha kecil mikro untuk bangkit dari krisis bukannya tanpa kendala. Kendala utama 
yang dihadapi oleh adalah aspek permodalan. Kecilnya omzet yang dimiliki oleh usaha mikro mengakibatkan peningkatan modal usaha juga berjumlah kecil. Usaha mikro juga jarang yang memiliki badan hukum sehingga kurang memiliki kekuatan pada aspek kelembagaan. Dua alasan ini menjadi penghambat serius untuk mengembangkan usaha mikro. Lembaga-lembaga keuangan formal pada umumnya memperlakukan UKM sama dengan Usaha Menengah dan Besar dalam setiap pengajuan pembiayaan, yang antara lain mencakup kecukupan jaminan, modal, maupun kelayakan usaha (cata$\tan$ kaki no. 5 di Wijono, 2005: 86).

Di samping itu, apabila berhasil memperoleh kredit untuk pengembangan usaha, usaha mikro harus mengembalikan dengan jumlah yang besar dan tidak sebanding dengan nilai kredit yang diangsur. Kondisi terjadi karena ketiadaan badan hukum mengakibatkan tingginya resiko untuk memberikan pinjaman pada usaha mikro. Lembaga-lembaga keuangan formal cenderung menetapkan bunga tinggi untuk kredit tanpa agunan.

Aspek administrasif dan waktu yang lama untuk pengajuan aplikasi kredit terkadang juga menjadi masalah tersendiri bagi pengusaha kecil. Masyarakat miskin sering mengabaikan ketentuan administratif karena menganggap urusan tersebut kadang berbiayai tinggi (misal: keharusan ada Kartu tanda penduduk atau surat ke- terangan usaha dari pejabat di daerah setempat). Pengurusan aplikasi kredit yang memakan waktu juga dihindari karena meninggalkan usaha untuk pengajuan aplikasi berarti harus me-ninggalkan peluang untuk mendapat-kan pembeli.

Solusi yang diambil oleh pengusaha mikro adalah mengambil kredit dari rentenir karena kendalakendala pengajuan kredit tidak ditemui dan berbeda dengan lembaga-lembaga keluangan formal. Di samping rentenir, usaha mikro bisa juga meminjam kepada Lembaga Keuangan Mikro (LKM). Namun sebaran LKM masih terbatas dan belum memiliki daya jangkau yang luas secara geografis.

\section{Lembaga Keuangan Mikro (LKM)}

LKM adalah lembaga yang menyediakan jasa penyimpanan (deposits), kredit (loans), pembayaran berbagai transaksi jasa (payment services) serta money transfers yang ditujukan bagi masyarakat miskin dan pengusaha kecil (insurance to poor and low-income households and their microenterprises) (ADB Online). Atau secara sederhana disebut sebagai lembaga yang biasanya memberikan layanan kredit kepada kelompokJ usaha berpendapatan kecil/mikro (Holloh, 2001: 2). Kredit mikro bertujuan untuk meningkatkan pandapatan dan membuka lapangan pe- 
kerjaan bagi masyarakat miskin dengan menyediakan akses layanan kouangan dari LKM (Holloh, 2001:
17). Menurut Permodalan Nasional Madani (Ismawan, 2002), kategori kredit terbagi menjadi:

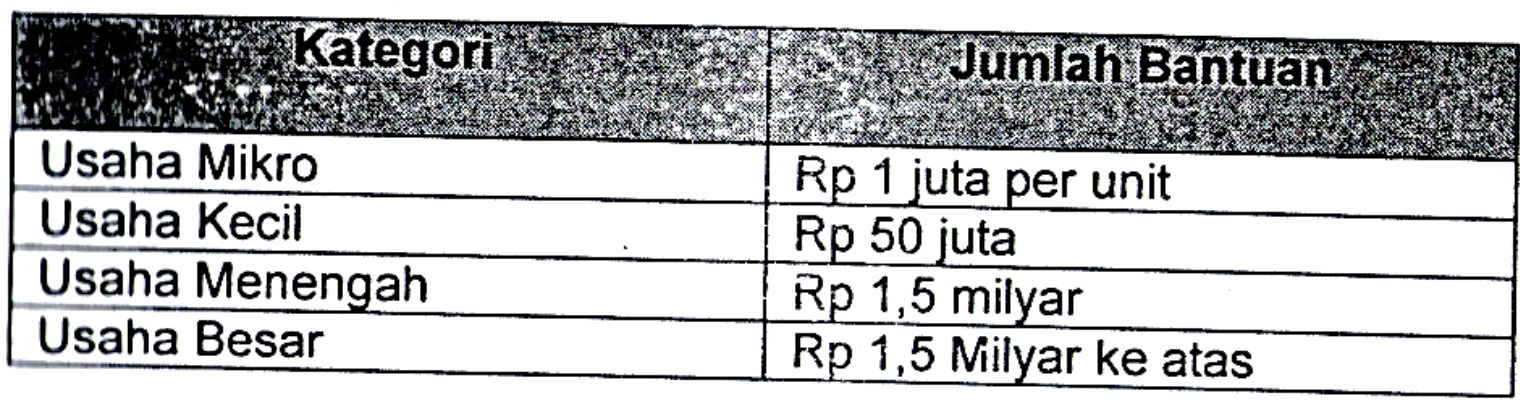

Tahun 2005 dicanangkan sebagai Tahun Keuangan Mikro. Indonesia adalah negara yang momiliki variasi terbesar dalam pengembangan model keuangan mikro di masyarakatnya sehingga dijadikan laboratorium dunia untuk keuangan mikro. Model LKM dibagi menjadi dua kategori, yakni lembaga yang berwujud bank dan non bank. LKM bank terdiri dari BRI Unit Desa, BPR dan BKD (Badan Kredit Desa) sedangkan non bank terdiri dari koperasi simpan pinjam (KSP), unit simpan pinjam (USP), lembaga dana kredit pedesaan (LDKP), baitul mal wattanwil (BMT), lembaga swadaya masyarakat (LSM), arisan, pola pembiayaan Grameen, pola pembiayaan ASA, kelompok swadaya masyarakat (KSM), dan credit union (Wiyono, 2005: 91).

\section{Baltul mal wattamwil (BMT)}

\begin{tabular}{lll}
\multicolumn{2}{c}{ Lembaga BMT adalah } \\
lembaga keuangan syariah \\
berbadan hukum yang berada
\end{tabular}

dalam Muamalah-net, yakni jaringan yang terdiri dari Bank Muamalat Indonesia, BPR Syariah, BMT, dan Koperasi Syariah. BMT bertujuan membantu ekonomi masyarakat muslim dengan plafon kredit mencapai maksimal Rp 5 juta rupiah (Holloh, 2001: 2). BMT juga memiliki nama lain, yaitu Koperasi Jasa Keuangan Syariah (KJKS) selanjutnya disebut KJKS adalah Koperasi yang kegiatan usahanya bergerak di bidang pembiayaan, invetasi, dan simpanan sesuai pola bagi hasil (syariah) (Microfin Indonesia On-line, 2006). Kegiatan usaha BMT meliputi:

1. Baitul Maal

a. Menghimpun dana ZIS anggota masyarakat sekitar BMT atau pun ZIS lembaga/ Perusahaan

b. Menyalurkan dana ZIS

2. Baitul Tamwil

Kegiatan Baitul Tamwil ini adalah usaha dibidang jasa Pelayanan Simpanan dan Pembiayaan serta Pembinaan Usaha yang ber- 
skala Mikro dengan pendekatan perseorangan dan Kelompok.

a. Jasa Pelayanan Simpanan Adalah kegiatan dalam menghimpun Dana Masyarakat dalam bentuk Simpanan baik simpanan yang penarikannya dapat dilakukan setiap saat atau Simpanan yang penarikannya dilakukan sesuai kesepakatan ( berjangka ).

b. Jasa Pembiayaan dan Piu$\operatorname{tang}$

Adalah kegiatan penyediaan dana untuk investasi atau kerjasama permodalan MT dengan Anggota. Ketentuannya adalah sipenerima pembiayaan diwajibkan untuk melunasi pokok pembiayaan sesuai dengan akad dan karekteristik Produk pembiayaan yang akan diterapkan di BMT.

\section{Peran Lembaga Keuangan Mikro}

LKM memiliki peran penting yakni intermediasi dalam aktifitas suatu perekonomian dan mengurangi biaya transaksi (Wijono, 2005: 89). Intermediasi berarti menjadi penghubung di tengah antara UKM dan perekonomian dalam masayarakat. Mengurangi biaya transaksi dengan wujud mem- berikan bantuan kredit sesuai kebutuhan UKM dan nilai kredit tidak berbanding terlalu jauh dengan jumlah pengembaliannya. Model BMT memberikan aksesibilitas dan sistem bagi hasil tidak memberatkan usaha kecil untuk mengembalikan kredit. Kelayakan usaha sebagai dasar dari pemberian bantuan juga disertai dengar bimbingan pengelolaan usaha. Jaminan keberlanjutan usaha tidak hanya menjadi tanggung jawab pengusaha sepenuhnya tapi juga BMT selaku pemberi bantuan.

Skema BMT berdasarkan syariah tapi secara umum dapat dikategorikan sebagai LKM yang berperan sebagai alat yang cukup penting untuk mewujudkan pembangunan. Peranan tersebut adalah menciptakan lapangan kerja, meningkatkan pendapatan masyarakat, dan mengentaskan kemiskinan (Strategi Nasional Pengembangan Keuangan Mikro).

\section{Kendala LKM}

Perbandingan permasalahan antara BMT dengan lembaga keuangan formal lainnya adalah: 


\begin{tabular}{|c|c|c|}
\hline $\begin{array}{l}\text { Landasan } \\
\text { Operasional }\end{array}$ & $\begin{array}{l}\text { - Bebas bermuamalah } \\
\text { selama tidak } \\
\text { bertentangan dengan } \\
\text { prinsip syariah dan } \\
\text { ketentuan yang berlaku } \\
\text { - Hasil usaha dalam } \\
\text { bentuk bagi hasil dan } \\
\text { margin jual beli barang. } \\
\text { - Uang bukan komoditi, } \\
\text { hanya sbg. alat tukar } \\
\text { (No Timie Value of } \\
\text { Money) } \\
\text { Dpt bertransaksi } \\
\text { finansial dan nyata }\end{array}$ & $\begin{array}{l}\text { - } \begin{array}{l}\text { Bebas bermuamalah } \\
\text { selama tidak } \\
\text { bertentangan dengan } \\
\text { ketentuan yang berlaku. }\end{array} \\
\text { - Hasil usaha adalah } \\
\text { bunga. } \\
\text { - Uang sebagai komoditi } \\
\text { yang dapat } \\
\text { diperdagangkan. } \\
\text { - Hanya danat melakukan } \\
\text { transaksi Financial. }\end{array}$ \\
\hline Fungsi dan Peran & $\begin{array}{l}\text { - Lembaga Intermediasi. } \\
\text { - Manager investasi } \\
\text { (Mudharib). } \\
\text { - Investor (Shahibul } \\
\text { Maal). } \\
\text { - Penjual dan Pembeli } \\
\text { barang. } \\
\text { - Pemberi Jasa } \\
\text { Keuangan } \\
\text { - Pengelola dana } \\
\text { kebajikan, ZIS. } \\
\text { - Hubungan dengan } \\
\text { nasabah adalah } \\
\text { hubungan kemitraan } \\
\text { (Mudharib dan Shahibul } \\
\text { mal). }\end{array}$ & $\begin{array}{l}\text { - Lembaga Intermediasi } \\
\text { Penghimpun dana } \\
\text { masya-rakat dan } \\
\text { meminjamkan kembali } \\
\text { kepada masyarakat } \\
\text { dalam kredit dengan } \\
\text { bunga. } \\
\text { - Pemberi Jasa Keuangan } \\
\text { - Hubungan bank dengan } \\
\text { nasabah adalah } \\
\text { hubungan debitur } \\
\text { dengan kreditur }\end{array}$ \\
\hline
\end{tabular}


Dari tabel diatas dan pemaparan tulisan tampak bahwa BMT memberikan keunggulan dalam skema bantuan. Namun BMT juga memiliki tanggung jawab besar untun melakukan pendampingan kepada usaha mikro yang dibantu. Petugas pendaminingan harus memiliki kemampuan administratif, teknis serta daya jelajah wilayah yang tinggi. Hal ini bisa meningkatkan biaya operasional. Kegagalan pendampingan juga bisa berakibat pada kegagalan usaha yang menjadi binaan BMT. Implikasinya bantuan yang diberikan BMT tidak dapat dikembalikan. Kondisi ini harus diatasi dengan manajemen pembiayaan yang kuat.

Hubungan kemitraan yang dibangun didasarkan asas kepercayaan - meskipun juga kelayakan usaha hal ini juga beresiko karena tidak ada jaminan asset. BMT harus selalu membangun komiunikasi dan keterbukaan sehingga resiko penggelapan dana tidak terjadi. Aspek keagamaan sebagai penopang hubungan bersifat sangat subyektif dalam membangun kepercayaan antara BMT dan nasabah.

Aspek kelembagaan yang dimiliki BMT cukup kuat karena harus berbadan hukum. Namun sebagai salah satu bentuk LKM, kebijakan yang mengatur BMT masih bergabung dengan lembaga keuangan konvensional sehingga peningkatan asset untuk pemberiar, bantuan ke UKM masih disamakan .
Skema bantuan yang
diberikan oleh LKM juga memberikan jaminan keamanan kredit tidak hanya kepada UKM tapi juga LKM. Sistem collateral substitute berupa tanggung renteng dan adanya social pressure dalam kelompok memungkinkan terciptanya tanggung jawab dalam setiap UKM untuk mengembalikan kredit (Ismawan, 2002). Macetnya pengembalian akan berdampak pada UKM lain yang menjadi kelompok usaha bersama.

\section{Kebijakan Untuk LKM}

Kebijakan pengembangan Keuangan Mikro dalam Kebijakan dan Strategi Keuangan Mikro adalah (KSKN, 2004):

1. Reorientasi peran pemerintah

a. menghentikan secara bertahap berbagai program yang memberikan subsidi suku bunga dan skim kredit untuk target sasaran tertentu

2. Lingkungan kondusif bagi keuangan mikro yang berkelanjutan

a. mengakui adanya berbagai jenis dan skala lembaga keuangan mikro diluar perbankan dan koperasi untuk memenuhi permintaan atas jasa keuangan yang beraneka ragam, terutama di wilayah pedesaan dan wilayah diluar Jawa dan Bali.

b. melegalisasi berbagai kegiatan lembaga keuangan mikro bukan bank bukan koperasi, termasuk 
kegiatan menghimpun simpanan masyarakat didalam wilayah dan didalam ambang batas tertentu.

c. mengintegrasikan keuang-an mikro kedalam sistem keuangan yang menyeluruh dan memberikan prioritas kepada keuangan mikro da-lam implementasinya.

3. Penyempurnaan peraturan berlandaskan prinsip kehati-hatian dan pengawasan secara lebih efektif

a. menciptakan kesempatan berusaha yang setara untuk berbagai lembaga keuangan mikro dan mencegah adanya arbitrasi pengaturan.

b. melindungi para penabung kecil dengan memberlakukan peraturan berlandaskan prinsip kehati-hatian, pengawasan dan penegakan hukum/aturan.

\section{Pengembangan kelembagaan} dan kapasitas usaha

Momusatkan upaya pemerintah pada penciptaan dan dukungan untuk pengembangan kelembagaan dan kapasitas usaha.

\section{Ponutup}

LKM di Indonesia menggelaja nobagai upaya untuk pemberdayaan ekonomi rakyat miskin. Sektor informal sebagai tulang punggung perekonomian rakyat keberadaannya selama Iiil didorong dan ditopang oleh LKM. llahkan karena besarnya jumlah LKM, Indonesia menjadi laboratorium dunia unluk bentuk-bentuk LKM. Kondisi ini seharusnya ditanggapi dengan serius oleh pemerintah dengan membuat Kebijakan yang mengatur LKM agar menjadi lebih kuat. Wujudnya dengan mengatur LKM tidak menjadi satu dengan peraturan perbankan.

Kebijakan perekonomian juga harus mendukung sektor industri rumah tangga/kecil (UKM) agar lebih berkembang. Bukti bahwa UKM mampu menggerakkan ekonomi rakyat miskin harus ditindaklanjuti dengan kebijakan yang mempermudah berkembangnya UKM. Plafon bantuan untuk UKM juga ditingkatkan paling tidak memiliki keseimbangan proposi - atau lebih besar dengan plafon untuk usaha diatasnya karena daya jangkau UKM terhadap masyarakat miskin untuk memberdayakan ekonomi lebih luas.

\section{Daftar Pustaka}

Andi Suruji, 2006, Terlepasnya Sektor Riil dari Indikator Makro, Kompas Cyber Media, http://www.kompas.com, diakses 18 Desember 2006 Anonim, 2002, Apa itu Kemiskinan dan Apa Penyebabnya?, SMERU research institute, www.smeru.or.id, diakses 16 Desember 2006 2006, Laporan Biro Pusat Statistik, Biro Pusat Statistik 
2002, Buku Paket Informasi

Dasar Penanggulangan Kemiskinan, SMERU research institute, www.smeru.or.id, diakses 16 Desember 2006 tanpa tahun, lihat di www.smeru.or.id, diakses 18 Desember 2006

2005, Peraturaii Bank Indonesia, Nomor

7/39/Pbi/2005, Tentang Pemberian Bantuan Teknis Dalam Rangka Pengembangan Usaha Mikro, Kecil Dan Menengah, pasal 1, di www.bi.go.id, diakses 18 Desember 2006

tanpa tahun, Microfin Indonesia, http://www.microfincenter.com, diakses 18 Desember 2006

2004, Kebijakan dan Strategi Nasional untuk Pengembangan Keuangan Mikro, diakses 18 Desember 2006

Bambang Ismawan, 2002, Pembiayaan Agribisnis, Jurnal Ekonomi Rakyat, Artikel Th. I No. 1 Maret 2002, http://www.ekonomirakyat.org, diakses 16 Desember 2006
Detlev Holloh, 2001, ProFl Microfinance Institutions Study, Promotion of Small Financial Institutions, Denpasar

Wiloejo Wirjo Wijono, 2005, Pemberdayaan Lembaga Keuangan Mikro Sebagai Salah Satu Pilar Sistem Keuangan Nasional: Upaya Konkrit Memutus Mata Rantai Kemiskinan, Kajian Ekonomi Dan Keuangan, Edisis Khusus

\section{Biodata Penulis}

Dwi Harsono, S.Sos dilahirkan di Purwokerto tanggal 15 Januari 1974. Sejak tahun 2001 menjadi dosen tetap pada Jurusan Pendidikan Administrasi Fakultas IImu Sosial dan Ekcnomi Universitas Negeri Yogyakarta dengan jabatan asisten ahli. 